\title{
Conservation of Diadegma semiclausum Hellen. Parasitoids as Biological Control to Plutella xylostella Linn. with Adult Food Exploration
}

\author{
Fri Maulina", Muflihayati* \\ Food Culture, Payakumbuh Agriculture Polytechnic, Tanjung Pati KM 7, 26271, Payakumbuh, Indonesia \\ E-mail:" maulinafri@yahoo.co.id,*aty_repris@yahoo.com
}

\begin{abstract}
Diadegma semiclausum Hellen. parasitoid (Hymenoptera : Ichneumonidae) is a potential natural enemy to Plutella xylostella Linn. larvae (Lepidoptera : Yponomeutidae) that attacks Brassicaceae crops (crucifers) such as cabbage (Brassica oleraceae var. capitata) and cauliflower (Brassica oleraceae var. italica). The failures of biological control programs caused by the lack of suitable charbohydrate food sources to adult parasitoid, and its effects the adult reproduction, so its important to use food sources which is suitable to $\mathrm{D}$. semiclausum longevity and fecundity for good existence in field. The aim of research is to identification kind of Brassicaceae wild flowers and to get a better Brassicaceae wild flowers as food to $D$. semiclausum adult parasitoids. This research has been conducted during the periods of Mei to November 2008 in laboratory and screen house of Payakumbuh Agriculture Polytechnic. This research consist of descriptive method to identification and a series with Completely Randomized Design. The last research is testing Brassicaceae wild flowers (Rorippa indica (Nasturtium indicum), Cardamine hirsuta, Bunias orientalis, $R$. indica ( $N$. heterophylum) as food of $D$. semiclausum adult parasitoids with four replications. Analysis of variance is performed on the data with SAS Systems. The result of research showed that brassicaceae wild flowers were testing a potential food sources for $D$. semiclausum adult but no one the best from its.
\end{abstract}

Keywords_Parasitoid; natural enemy; Brassicaceae; longevity; fecundity

\section{INTRODUCTION}

Diadegma semiclausum Hellen. parasitoid (Hymenoptera : Ichneumonidae) is a potential natural enemy to Plutella xylostella Linn. larvae (Lepidoptera : Yponomeutidae) that attacks Brassicaceae crops (crucifers) such as cabbage (Brassica oleraceae var. capitata) and cauliflower (Brassica oleraceae var. italica) [1], [2].

The failures of biological control programs caused by the lack of suitable charbohydrate food sources to adult parasitoid, and its effects the adult reproduction, so its important to use food sources which is suitable to $D$. semiclausum longevity and fecundity for good existence in field. Since the D. semiclausum was introductions from Selandia Baru to Indonesia at 1950, its reported establish in brassicaceae production center, includes West Sumatera [3]. But its effectivity to control $P$. xylostella larvae not good and in fluxtuation from $58,0 \%-63,2 \%$ [4], [5].

Not maximal effectiveness of this parasitoid is partly due to the high intensity of the use of pesticides by farmers (2-3 $\mathrm{x}$ a week) (personal communication) because these pests attacking start from seed to harvest [6],[7]. However, this pest has been reported to persist even resistant to synthetic insecticides and microbes such as Bacillus thuringiensis [7][9]. The occurrence of resistance to $P$. xylostellla to insecticides caused farmers intensified spraying, so the parasitoid D. semiclausum are not targets also experience death (extinction).

Additionally habit farmers to control weeds in a clean (clean wedding) and planting cabbage in monoculture led adult parasitoid insects do not have a place of refuge (refugia) for a temporary shelter at the time did not support the native habitat such as during intensive spraying and harvesting. As a result, even the death of the natural enemies of pests such as the extinction of the parasitoid $D$. semiclausum unavoidable. According [10], natural enemies of stability is strongly influenced by the diversity and structure planting in the field.

Natural enemy conservation measures can be done in various ways, among others: 1) the management of wild plants from insects to host plants are either native or alternative hosts, and shelter as well as natural enemies; availability of feed imago parasitoid mainly nectar (honey water), pollen (flour juice) and honey dew, and, 2) reducing the use of insecticides. According [11], the conservation work will add to the efficacy of biological control using 
natural enemies. Conservation of biological agents include manipulation of the environment to increase longevity and fecundity of natural enemies, changing behavior (temperament) and provides a reservoir (of protection) from unfavorable environmental conditions.

Feed supply directly as a source of carbohydrate in agroecosystems can help the maintenance of local populations of natural enemies as biological control of pests. Therefore feed impact both on parasitoid longevity and fecundity to note that its presence in the field better. The discovery of wild flowering plants Brasicaceae needs to be studied and tested for its effectiveness in the laboratory before being run on the field.

The use of parasitoids D. semiclausum as natural controllers of $P$. xylostella larvae can not be separated from the mass propagation of parasitoid activity in the laboratory. This relates to its availability in large quantities with a high level of fitness to be released into the field. The use of honey as a feed substitute in the propagation is common practice, however, the recommended standard concentration (10\%) tend not favored by imago parasitoid D. semiclausum, while the $100 \%$ concentration is preferred but are at risk of death if the body parts imago. It is therefore necessary to find the most ideal concentration is best for mass propagation of fitness and success in the laboratory. According [12], biological control program failure can be caused by lack of due fodder for adult parasitoids.

The purpose of this study was to identification kind of Brassicaceae wild flowers and to get a better Brassicaceae wild flowers as food to D. semiclausum adult parasitoids

\section{METHODS}

This research has been conducted in the laboratory and screen house of Payakumbuh Agricultural Polytechnic at seven months, from May to November 2008. Exploration (inventory) and larva sampling conducted in Agam cabbage.

The study consisted of two 2) stages of the work are: 1). Exploration of wild Brasicaceae as a source of feed to imago parasitoid $D$. semiclausum with descriptive survey method on a central planting cabbage in Agam District. Brasicaceae wild flowering plants are found in field identified based weed identification book and then tested in the laboratory as a feed imago parasitoid D. semiclausum. 2). Testing of wild Brasicaceae species as a source of feed imago parasitoid D. semiclausum. Tests were conducted at four (4) types of wild Brasicaceae flowering most dominant of exploration results on cabbage crop land. This test using completely randomized design (CRD) with 4 treatments and 4 replications. Observed data were analyzed with a variety of SAS system followed by DNMRT advanced test at $5 \%$ level. The parameters measured were the type (species) of wild Brasicaceae, longevity and fecundity of D. semiclausum with the wild Brassicaceae food.

\section{RESULT AND DISCUSSION}

\section{A. Exploration of Wild Species as a Source of Feed Brasicaceae Adult parasitoid D. semiclausum}

Inventory conducted in cabbage fields shows that quite a lot of wild flowering plants that exist, besides it Brassicaceae plant species cauliflower (Brassica oleracea var.italica) were deliberately made too many seeds in the field. Identification by providing an overview there are 4 types of wild flowering plants belonging to the Brassicaceae Rorippa indica (Nasturtium indicum), Cardamine hirsuta,

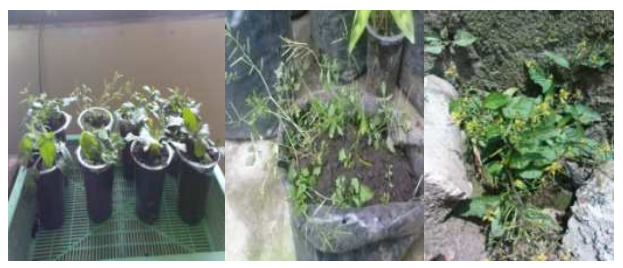

Fig. 1 Wild Brassicaceae plant identification result a. Rorippa indica (Nasturtium heterophlum) b. Cardamine hirsuta c. $R$. indica (N. indicum)

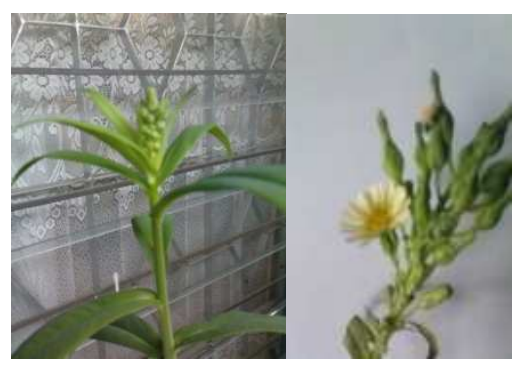

Fig. 2 Wild brassicaceae plant identification results Bunias orientalis, a. Before flowering b. After flowering

TABLE I

KIND OF WILD FLOWERING PLANTS THAT ARE FOUND AROUND THE LAND CABBAGE

\begin{tabular}{|c|c|c|c|}
\hline No & Species & $\begin{array}{l}\text { Color of } \\
\text { flowers }\end{array}$ & Family \\
\hline 1. & $\begin{array}{l}\text { Rorippa indica (Nasturtium } \\
\text { indicum) }\end{array}$ & Yellow & Brassicaceae \\
\hline 2. & Cardamine hirsuta & White & Brassicaceae \\
\hline 3 . & Bunias orientalis & Yellow-White & Brassicaceae \\
\hline 4. & $\begin{array}{l}\text { Rorippa indica (Nasturtium } \\
\text { heterophylum) }\end{array}$ & Yellow & Brassicaceae \\
\hline 5. & Sonchus arvensis & Yellow & Asteraceae \\
\hline 6. & Ageratum conyzoides & White & Asteraceae \\
\hline 7. & Portulaca olearaceae & Yellow & Portulacaceae \\
\hline
\end{tabular}

Bunias orientalis, Rorippa indica (N. heterophylum) (Fig. 1 and 2). Differences $N$. indicum with $N$. heterophylum look at the composition of interest groups (panicles) and more on $N$. indicum. Wild flowering plant species not found in the Brassicaceae dominant land is Sonchus arvensis, Ageratum conyzoides, Portulaca olearaceae (Table 1). Wild flowering plant family Brassicaceae which is found further tested as feed imago parasitoid D. semiclausum in the laboratory.

\section{B. Testing of Wild Species as a Source of Feed Brasicaceae Adult Parasitoid D.semiclausum \\ (1). Longevity}

Results of analysis of variance test four (4) wild Brassicaceae species have been identified from the cabbage fields imago parasitoid D. semiclausum in the laboratory (daily temperature during the study $26^{\circ} \mathrm{C}-30^{\circ} \mathrm{C}$ ) did not give 
a significantly different effect on the long life imago parasitoid females and males (Table 2).

Longevity of adult $D$. semiclausum females tend to be longer than in males, with an average of 4.3 and 3.1 days respectively. Although the treatment of Brassicaceae wild flowers, but there was no difference when compared with no feeding (only water) (Table 4) it is seen that the Brassicaceae wild flowers can add long-life female parasitoid D. semiclausum of an average 1.75 to 4.10 days (approximately $2 \mathrm{x}$ ). According [13], flower nectar contain a lot of glucose and amino acids that can increase the metabolism of insect parasitoids.

Reference [12] showed that with feed derived from sweet alyssum flowers (Lobularia maritime) (Brassicaceae) give effect to a long life of Diadegma insulare (Cresson) (Hymenoptera, Ichneumonidae) 12 times longer than with consuming water only (control). According [12], that a long life D. semiclausum increased from 2 days to 30 days respectively from consuming water and buckwheat (Fogopyrum esculentum cv.Katowase Moench

\section{(2). Potensial Fecundity}

Potential fecundity imago D. semiclausum also does not provide results that are statistically significantly different (Table 3).

However, when compared to the numbers seen that there is a potential increase in egg with wild flowers Brassicaceae feeding compared with no feeding (only water) which is an average of 36.8 and 49.4 days.

\section{TABLE III}

LONGEVITY OF ADULT D. SEMICLAUSUM PARASITOID WITH BRASSICACEAE WILD FLOWER FEED TREATMENT FROM EXPLORATION RESULTS

\begin{tabular}{|l|c|c|}
\hline \multicolumn{1}{|c|}{ Treatment } & $\begin{array}{c}\text { Longevity } \\
\text { female }+ \\
\text { (days) }\end{array}$ & $\begin{array}{c}\text { Longevity } \\
\text { male } \\
\text { (days) }\end{array}$ \\
\hline $\begin{array}{l}\text { Rorippa indica (Nasturtium } \\
\text { heterophylum) }\end{array}$ & $4.75 \mathrm{a}$ & $3.00 \mathrm{a}$ \\
Cardamine hirsuta & $4.25 \mathrm{a}$ & $2.75 \mathrm{a}$ \\
Bunias orientalis & $4.00 \mathrm{a}$ & $3.75 \mathrm{a}$ \\
Rorippa indica (Nasturtium indicum) & $4.00 \mathrm{a}$ & $2.75 \mathrm{a}$ \\
\hline
\end{tabular}

The numbers in the same column followed by different lowercase,significantly different according DNMRT test at 5\% significance level.

TABLE IIIII

ADULT FEMALE FECUNDITY D. SEMICLAUSUM WITH TREATMENT BRASSICACEAE FEED WILD FLOWER EXPLORATION RESULTS

\begin{tabular}{|l|c|}
\hline \multicolumn{1}{|c|}{ Treatment } & $\begin{array}{c}\text { Potensial fecundity } \\
\text { female } \\
\text { (eggs) }\end{array}$ \\
\hline Rorippa indica (Nasturtium heterophylum) & $60,75 \mathrm{a}$ \\
Cardamine hirsuta & $47,50 \mathrm{a}$ \\
Bunias orientalis & $50,25 \mathrm{a}$ \\
Rorippa indica (Nasturtium indicum) & $39.00 \mathrm{a}$ \\
\hline
\end{tabular}

The numbers in the same column followed by different lowercase, significantl different according DNMRT test at $5 \%$

\section{CONCLUSIONS AND SUGGESTION}

Brassicaceae plants wild flowers from the field can be used as feed imago parasitoid $D$. semiclausum but there has not been the best among the 4 treatments (Rorippa indica (Nasturtium indicum), Cardamine hirsuta, Bunias orientalis, Rorippa indica (N. heterophylum)) were tested.

Further testing needs to be done in the field in order to obtain more accurate results.

\section{ACKNOWLEDGMENT}

This work was supported by food plant laboratory at Payakumbuh Agriculture Polytechnic. I would like to thanks to everybody who support this research

\section{REFERENCES}

[1] T.J Smith, and M.H Villet. Biological control of Diamondback moth, Plutella xylostella, in cabbage fields in the Eastern cape, South Africa. In International symposium on improving biocontrol of Plutella xylostella. Montpellier, France. 21-29 Oct. 2002.

[2] A. Krishnamoorthy. Biological control of Diamondback moth Plutella xylostella L. an Indian scenario with reference to past ang future strategies. In International symposium on improving biocontrol of Plutella xylostella. Montpellier, France. 21-29 Oct. 2002.

[3] H.C.C.A.A. Vos. Introduction in Indonesia of Angitia cerophaga Grav., a parasites of Plutella muculopennis Curt. Contrib. Ent.Agric. res. Stat. Bogor, No 134. 32 p. 1953.

[4] F. Maulina. Peranan parasitoid Diadegma eucerophaga dalam menekan populasi larva Plutella xylostella. Artikel ilmiah. Politeknik Pertanian Universitas Andalas. Tanjung Pati Payakumbuh. 12 p. 1995.

[5] E.Hatta. Fluktuasi popolasi hama Plutella xylostella L. (Lepidoptera : Plutellidae) dan musuh alaminya pada tanaman kubis (Brassica oleraceae var. capitata). Thesis. Program Pascasarjana Universitas Andalas Padang. p 25-42. 2000.

[6] J.R. Muckenuss, B.M. Shepard, and E.R.Ferrer. Natural mortality of Diamondback moth in coastal South Carolina. In Diamondback moth and other crucifer pest: Proc. 2 nd Inter.Workshop, Tainan, Taiwan, 10-14 December 1990. Asian Veg. Res and Dev, Center. Pub. 92-368. Shanhus, Tainan, Taiwan. Pp 2-36. 1996

[7] ENY. Diamondback moth Plutella xylostella L One of series of entomology \& nematology Departement, Florida Cooperative Extension Service, Institute of food and Agricultural Sciences, University of Florida. Sept. 2004.

[8] T.A. Hill, and R.E.Foster. Effect of insecticides of Diamondback moth (Lep : Plutellidae) and its parasitoids Diadegma insulare (Hym : Ichneumonidae). Jurnal Horticultural Entomology. 00220493/00/0763-0768\$02.00/0. 2000.

[9] B.E. Tabashnik, N.L. Cushing, N. Finson, and M.W. Johnson. Field development of resietance to Bacillus thuringiensis in Diamondback moth ((Lepidoptera : Yponomeutidae). J. Econ. Entomol. 83: 16711676. 1990.

[10] R. Sutanto. Pertanian Organik: Menuju pertanian alternatif dan berkelanjutan. Penerbit Kanisius. Yogjakarta. 218 p. 2006.

[11] S.D. Wratten, B.I. Lavandero, J.Yulianakis, T. Cilgi, and R.Sedcole. Effect of Flowers on parasitoid longevity and fecundity. New Zealand Plant protection 56 : 239-245. 2003.

[12] D.L. Johanowics, and E.R. Mitchell Effect of sweet alyssum flowers on the longevity of parasitoids wasp Cotessia marginiventris (Hymenoptera : Braconidae) and Diadegma insulare (Hym : Ichneumonidae). Jurnal Florida Entomologist 83(1): 41-47. 2000

[13] A.B. Idris. Ecology ang behavior of Diadegma insulare (Cresson), a biological control agent of Diamondback moth Plutella xylostella L. Dissertation, Michigan State University. 205 p. 1995. 